Turkish Psychological Counseling and Guidance Journal

Türk Psikolojik Danışma ve Rehberlik Dergisi
Beşaltı \& Kul (2021)

Vol: 11 Number: 63 Page: 505-520 ISSN: 1302-1370

RESEARCH

Open Access

ARAŞTIRMA

Açık Erişim

\title{
Effects of a Game-Based app on Primary Students' Self Efficacy and Achievements in Learning Fractions During Distance Education
}

\section{Uzaktan Eğitim Sürecinde Oyun Tabanl Bir Uygulamanın Illkokul Öğrencilerinin Kesirleri Öğrenmede Öz-yeterlik ve Basarilarna Olan Etkisi}

\section{Metin Beşaltı ๑, Ümit Kul $\odot$}

\begin{tabular}{l}
\hline Authors Information \\
Metin Beşaltı \\
Assistant Professor, Artvin Çoruh \\
University, Artvin, Turkey \\
besalti@artvin.edu.tr \\
Ümit Kul
\end{tabular}

Associate Professor, Artvin Coruh

University, Artvin, Turkey

umitkul@artvin.edu.tr

\begin{abstract}
Fractions have great importance for primary students in mathematics education and are one of the most problematic concepts they encounter in their school life. This research study aimed to examine the effectiveness of a game-based app (Slice Fractions) to help students to develop their academic performance and self-efficacy in fraction skills during distance education. A total of 142 fourth grade students from eight different classes participated to the study. A quasi-experimental method was used to assess the impact of the Slice Fractions game on student learning and self-efficacy of the concept of fractions in the fourth-grade math course. The self-efficacy scale and the diagnose test for fractions were applied to the fourth-grade students. The results showed that the students in the game group had significantly better learning performance in fractions than students in the non-game group. Similarly, the students in the game group had significantly better self-efficacy in fractions than students in the non-game group.
\end{abstract}

\section{ÖZET}

Matematik eğitiminde büyük önem taşıyan kesirler konusu ilköğretim öğrencilerinin okul hayatlarında karşılaştıkları en problemli kavramlardan birisidir. Bu çalışmanın amacı, uzaktan eğitim sırasında oyun tabanlı bir uygulamanın (Slice Fractions) öğrencilerin kesirler konusundaki akademik performanslarını ve öz yeterliklerini ne denli geliştirmelerine olanak sağladığını incelemektir. Araştırmaya sekiz farklı sınıftan toplam 142 dördüncü sınıf öğrencisi katılmıştır. Çalışmada yarı deneysel araştırma yöntemi kullanılarak Slice Fractions oyununun öğrencilerin kesirler kavramını öğrenmesinde ve öz-yeterlik konusunda etkisi araştırılmıştır. Araştırmaya katılan öğrencilere kesirler öz-yeterlik ölçeği ve kesirler başarı testi uygulanmıştır. Yapılan analizler sonucunda, oyun grubundaki öğrencilerin, oyun oynamayan gruptaki öğrencilere göre kesirlerde önemli ölçüde daha iyi öğrenme performansına ve daha iyi öz-yeterliğe sahip oldukları sonucuna varılmıştır.

Received: $27 / 09 / 2021$

Revision: $24 / 11 / 2021$

Accepted: 17/12/2021

Cite this article as: Beşaltı, M., \& Kul, Ü. (2021). Effects of a game-based app on primary students' self efficacy and achievements in learning fractions during distance education. Turkish Psychological Counseling and Guidance Journal, 11(63), 505-520. 


\section{INTRODUCTION}

Fractional concepts in mathematics education are difficult and complex to understand for both students and adults (Hecht et al., 2007). It is one of the abstract concepts that form the basis of daily life issues relevant to rational numbers and problems (Charalambous \& Pitta-Pantazi, 2005; Naiser et al., 2004) and that students encounter for the first time in school life (Olkun \& Toluk-Uçar, 2014). It is known that the concept of fractions was used to describe amounts less than one whole in a variety of civilizations since ancient times (Cajori, 1999). Today, the topic of fractions is included in almost every stage of formal education. In fact, the concept of the fraction begins in the pre-school period with quarter and half concepts, with awareness of whole and half fractions in 1st grade of primary school, and then the association of quarters with whole and half concepts given in 2 nd grade. In 3rd grade, the part-whole relationship is emphasized and concepts related to fractions are described and the unit fraction concept is considered to reinforce the relationship between numerator and denominator and finally, in 4th grade, students are expected to define and use simple, combined, and whole number fractions. Additionally, the objective of the 4th-grade curriculum is to add and subtract fractions with equal denominators (MEB, 2018). Early fractions difficulties seen in schools are a significant indicator for future achievement in mathematics (Watts et al., 2014). In this sense, fraction plays an important role in enhancing mathematics topics such as algebra or geometry and in high functioning skills for a productive and successful life (Bailey et al., 2012; Haser \& Ubuz, 2003; Siegel et al., 2010; Siegler et al., 2013; Aksu \& Konyalığlu, 2015). However, it is well known that students, and even teachers, experience a range of difficulties in learning fractions, such as having misconceptions about whole numbers as decomposable units (Ni \& Zhou, 2005), misunderstanding the part-whole notion of fractions (Brousseau et al., 2004), and conceptual and procedural understanding of fractions (Gabriel, et al., 2013) which are associated with many mathematical concepts (Hecht \& Vagi, 2012; Lortie-Forgues, et al., 2015). Due to the structural diversity and complexity of fractions, it is a process that requires time and careful planning for student conceptual learning at every school level (Alacaci, 2015; Pesen, 2007).

Developing students' self-efficacy beliefs and learning achievement has been viewed as a challenging issue in mathematics education (Peters, 2013; Soylu \& Soylu, 2005). Researchers have attempted to cope with this issue by offering effective teaching approaches or digital tools in traditional teaching environments (Hung et al., 2014). As the impact of developments in technology on education becomes more widespread, learning environments and instructional contents have begun to be designed in a way that is independent of time and space. Due to the difficulties experienced related to fractions and the importance of fractions in the curriculum, educators and teachers have oriented toward discovering new technological devices such as iPads, smartphones, and Kindles to make this concept more meaningful for students. In fact, findings obtained from studies in the literature show that with the popularization of mobile devices, the number of studies on mobile learning is increasing every year, are beneficial, and can be used for learning and teaching mathematics. Most research supports the idea that the effective use of mobile tools can improve mathematics teaching and increase the academic performance of students (Musti-Rao \& Plati, 2015; Zhang et al., 2015). Additionally, the use of mobile technology is unavoidable due to advantages like visualization of fractions, the ability to make changes to the visual representations through technology, and the ability to learn at an individual pace (Bruce \& Ross, 2009; Suh \& MoyerPackenham, 2008). Through the use of the game-based mobile application in education, it is more convenient to explain mathematical concepts with interactional multiple representations (Riconscente, 2011). Mobile learning provides important opportunities for students to meet the individual differences 
and needs of students in a challenging subject such as fractions. Therefore, the Slice Fractions is an awardwinning fraction game and is an incredibly fun way to learn fractions. In this context, the question that comes to mind is "how a game-based mobile application (Slice Fractions) affects the academic achievement and self-efficacy of fourth-grade students' learning about fractions in comparison with traditional instruction? In order to answer this question, first of all, studies that focus on the importance of fractions in learning and the use of mobile learning in mathematics education have been compiled by reviewing the relevant literature and presented to support the theoretical background of the study.

\section{Theoretical Framework}

\section{Fractions and Self-Efficacy}

Fractions have great importance for primary students in mathematics education and are one of the most problematic concepts they encounter in their school life. Despite this importance, theoretical and empirical-based studies reflect that students and even teachers have some misconceptions and difficulties about fractions for a variety of reasons, factors may be listed as; natural number bias (Van Hoof et al., 2018), symbolic representation (DeWolf et al., 2015), teaching form of fractions (İpek et al., 2005), learning with a rule-based approach (Bulgar, 2003), not perceiving a fraction as a number but seeing it as a certain portion/amount of a shape/whole (Kerslake, 1986), perceiving the numerator and denominator of fractions as two different whole numbers (Cramer \& Whitney, 2010; Siegler et al., 2011), inability to distinguish parts with equivalent value to the whole (Haser \& Ubuz, 2003) and fractions having more than one meaning (Dickson et al., 1993).

In order for students to have a sturdy foundation for the fraction concept, it is necessary to concretize and visualize how fractions work. After teaching natural numbers at the primary school level, when fractions begin to be taught, especially, students experience difficulty understanding the topic; this situation creates an effect on the students' performance, self-efficacy, and attitudes about fractions (Soylu \& Soylu, 2005). Related to this, when a student is learning a topic, high self-efficacy related to that topic is crucial for learning. Bandura (1982) expressed the self-efficacy concept as personal judgments related to what a person can do if they encounter a probable situation. According to Kauchak and Eggen (1998), the self-efficacy beliefs of an individual are a good motivation component for learning. People with high self-efficacy beliefs about any topic were identified to expend more effort to succeed in the process of working at something and did not immediately give up to succeed at the work (Bonne \& Johnston, 2016). Contrary to this, people with low self-efficacy beliefs feel stressed in the process of succeeding at something and are said to be aggressive in situations (Bandura, 1997). People are expected to have strong self-efficacy beliefs to reveal competency in learning processes and not to experience negative feelings. If it is considered that the topic of fractions is generally a complicated concept for students, promoting the self-efficacy of students about fractions carries great importance in the name of changing this idea.

Research shows that when the fraction concept is not learned well, it negatively affects the learning of other topics in mathematics like rational numbers, decimals, and percentages, ratio and proportions, operations with fractions, algebraic expressions, and equations (İpek et al., 2005). For this reason, developing fractions sense is very important for basic mathematics education (MEB, 2018). In order to resolve difficulties experienced by students in fractions teaching and to support better comprehension of the concept of the fraction, the use of multiple representations is recommended (Cramer et al., 2008; Eroğlu, et al., 2019). According to Pesen (2007), the 'part-whole' relationship concept is very important when teaching fractions. Sowder (1995) stated that comparisons of part-whole in fractions involve 
physical or mental actions. There is no limitation about the area, length, and cluster models that can be used to show the part-whole relationship. Cramer et al. (2008) and Olkun and Toluk-Uçar (2014) stated that circle-rectangle area models were effective to show this relationship. Additionally, when students perform comparison and ordering processes for fractions, they need to be aware that they are working with a 'whole' with the same dimensions. Misunderstanding of this concept will cause errors in comparing and ranking fractions. For this reason, rather than passing over symbolical representation quickly before developing a conceptual understanding, it is important to develop number sense related to fractions which students have less probability of forgetting (Jones, 2012; Lamon, 2012).

\section{Mobile learning (The Use of Game-based app in Education)}

Game-based mobile learning is becoming very popular because they improve learners' achievement in mathematics (Fabian et al., 2016). In addition to this, game-based apps offer entertaining activities, learners' motivation on task was developed, and it encouraged students to learn problematic topics (Carr, 2012). With regards to the feature of digital games, these games, such as Slice Fractions (one of the apps to teach the notions of the fraction to students who are the age of 8-12), might help them to increase mathematics learning by developing their self-efficacy beliefs for attempting to solve a problem over and over when they are not successful. Playing digital games develops the enjoyment and interest of students in learning mathematics (Cyr et al., 2019). Moreover, these game-based apps could be utilized as virtual manipulatives (Riconscente, 2013).

Berch and Mazzocco (2007) stated that conceptual understanding and fraction sense are interchangeable, and interacting with mathematics games has the potential to develop mathematical skills. One of the methods assisting in developing fractions sense is the use of manipulatives and pictorial representations of fractions (Long et al., 2015). In this sense, breaking up sections, gluing, and overlapping activities are frequently used with technological tools or a variety of geometric shapes. In this context, it is important to ensure meaningful learning with concretization and modeling through multiple representations of abstract concepts like fractions by students (Van de Walle et al., 2013).

There are limited studies in the literature assessing the effect of the game-based app about fractions on 4th-grade students' learning achievements and self-efficacy. For example, the semi-experimental study by Cyr et al. (2019) identified that a mobile-based slice fraction game positively contributed to student success about fractions. Additionally, they revealed that learning was more affected compared to other traditional methods and that it played a potential role in making the teaching-learning process more efficient. Another positive aspect of mobile learning appears to be the role in making it easier to learn abstract concepts by concretization (Lee, 2010). In this sense, mobile-based applications are a very important material in the sense of the efficiency of the learning environment. A study by Masek et al. (2017) found that the experiment group with access to games in addition to direct teaching received higher points compared to control group students. When students with lower levels of fraction skills are examined especially, students with access to games appeared to have larger developments in skills.

There are a limited number of studies on the effect of using a game-based application on students' achievement and self-efficacy in Turkey. Thus, more attention has been directed in general towards students' attitude, motivation, perception of the use of mobile technology in the mathematics context. Riconscente (2013) expressed that there is no study including controlled experiments that assessed the effectiveness of a game-based mobile app for increasing learning outcomes. Based on all of these, in this 
study, the aim was to use a game-based mobile application in the distance education process to ensure concretization and meaning through multiple representations or modeling of abstract concepts with technology, which has an important place in the lives of students today. In line with this aim, the facility to use a digital game called slice fractions ensuring the opportunity to associate the fractions topic in teaching with mathematics in the daily life of students with distance education was provided. For this reason, the effect of a game-based application developed for the fractions subsidiary learning area, one of the basic concepts included on the 4th-grade mathematics lesson curriculum, on academic success and self-efficacy related to the mathematics of students was investigated.

\section{The Purpose of the Research}

Within the scope of this research, it will be investigated how a game-based application in the distance education process affects the academic achievement and self-efficacy of fourth-grade students' learning about fractions. In line with this aim, answers to the following questions were sought:

(1) What is the development of academic performance and self-efficacy about fractions of 4th-grade students in the experimental group?

(2) What is the development of academic performance and self-efficacy about fractions of 4th-grade students in the control group?

\section{METHOD}

\section{Research Model}

In this study, the quasi-experimental method was used to assess the impact of the Slice Fractions game on student learning and self-efficacy of the concept of fractions in the fourth-grade math course. The objective of the unit was to educate the students learning of the concept of fractions. For this purpose, a quasi-experimental design with experimental-control groups was used. The quasi-experimental method is one of the methods commonly used in educational research (Cohen \& Mannion, 1994). The purpose of this method is to test how the change seen in one group is different from the change in the other (Büyüköztürk, et al., 2008). The independent variables were the different types of learning, while the dependent variables were learning achievement and self-efficacy scores on learning fractions. The selfefficacy scale for fractions and the diagnose test for fractions were applied to the 4th-grade students in both the experimental group and the control group before the subject of fractions was explained. The change in students' achievement and self-efficacy regarding fractions was examined.

In this study, two different types of math classes were compared. A total of four traditional classes were assigned to the control group (non-game group) and four-game classes assigned to the Slice Fractions experimental group (game group). A total of eight classes included the same learning objectives and content.

Based upon the literature review, the following hypothesis formulations were tested:

- Students in the game group would have significantly better performance in learning fractions than students in the non-game group.

- Students in the game group would have significantly better self-efficacy in fractions than students in the non-game group. 


\section{Participants}

The participants were randomly selected from the primary schools in the city of Artvin, located in the northeastern part of Turkey. In total, 142 fourth-grade students (64 boys and 78 girls) from eight different classes agreed to participate in this study. All participants were aged from 10 to 11 years old. They also had the same learning objectives and content related to fractions during the study. Each class was randomly assigned to one of the following groups: the traditional non-game group (4 classes) and the game group (4 classes).

\section{Ethical Statement}

All procedures performed in studies involving human participants were in accordance with the ethical standards and with the Helsinki Declaration and its later amendments or comparable ethical standards. Informed consent was obtained from all individual participants included in the study. In line with this, the study was permitted by Artvin Coruh University Scientific Research and Ethical Review Board.

\section{Material}

Slice Fractions Game: The participants in the game group interacted with Slice Fractions game during the study. The game was developed by a team of learning experts from the University of Quebec in Montreal. The main purpose of the game was to increase students' understanding of abstract and symbolic elements of fractions. By playing the game, students were expected to learn the following concepts;

- Part-whole partitioning: Understand how to slice one whole into equal shares

- Fraction symbols: Understand that a numerator counts as equal parts.

- Fraction reading: Understand how to read fractions.

- Numerator / Denominator notation: Understand how to use numerator and denominator

- Pie charts: Understand how to use pie charts to represent fraction values.

- Fraction equivalence: Understand how to use equivalent fractions.

- Fraction ordering: Compare fractions successfully

- Fraction addition: Understand how to add additional block fractions to ice block fractions

In the game, students must move a woolly mammoth forward by removing obstacles that block its path to find its family. To do that, they must slice through pieces of ice and lava. Students must figure out on their own how to associate equivalent parts of ice and lava to clear out the mammoth's path (See Figure 1). 

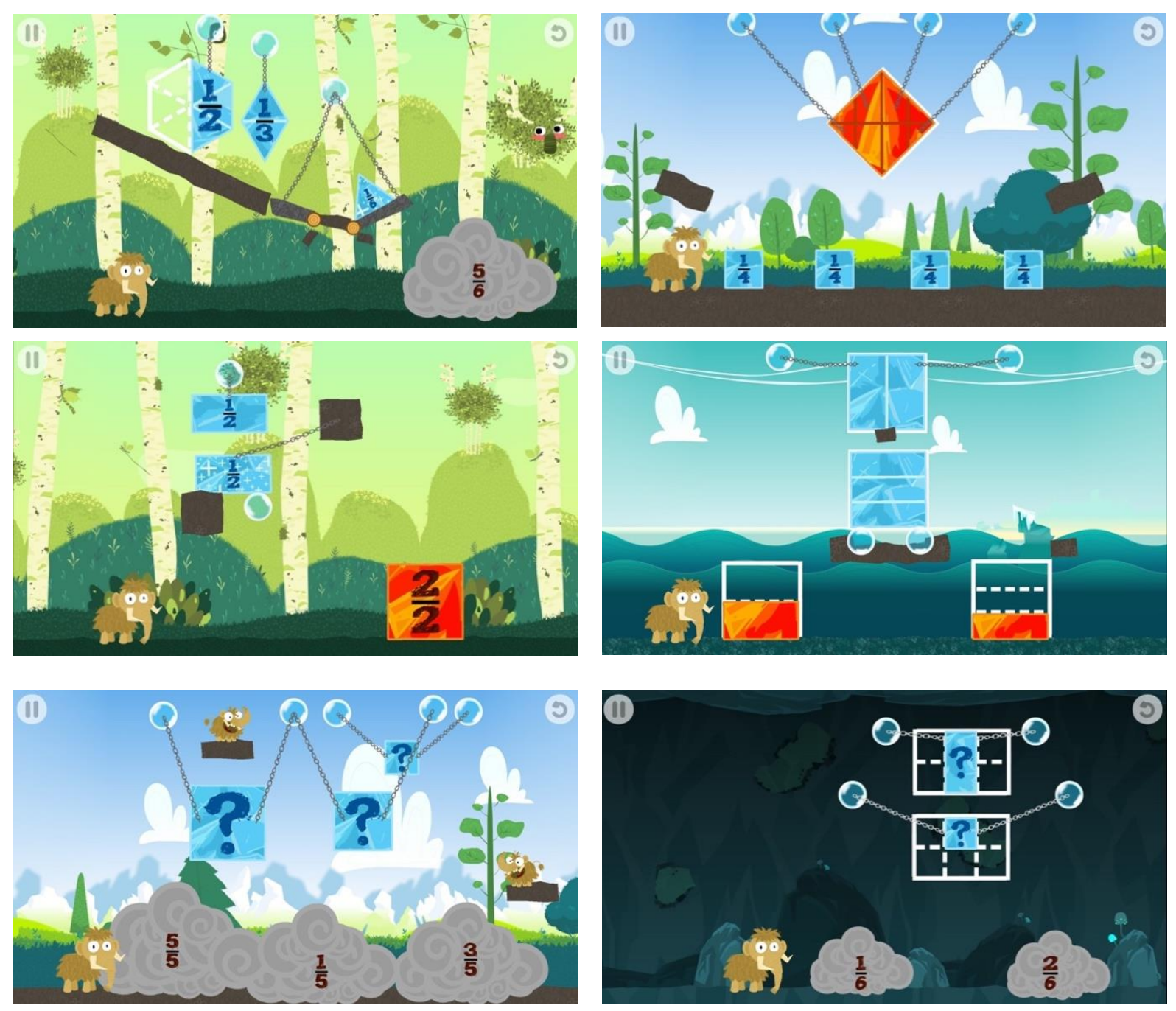

Figure 1. Example of different levels showing the game's progression

\section{Instruments}

TIMMS Knowledge Test. The pre and post-knowledge test questionnaires about fractions were designed to assess students' knowledge of fraction concepts during the study. The questions were picked from the Trends in International Mathematics and Science Study (TIMMS) exams for 4th grades from 2011 to 2019. The knowledge test included 15 multiple-choice questions on fractions concepts, which were derived from both the learning objectives of the course and the concept of the Slice Fractions game. To adequately measure student progress, the same questions with different orders were used in both pre and post-tests. Therefore, students in both classes would need to remember the same information to be able to answer the knowledge test questionnaires.

Self-efficacy Scale. In this study, a scale of self-efficacy of primary school students towards fractions developed by $\mathrm{Uz}$ (2018) consisting of 18 items under 4 sub-dimensions in total was used. This scale is a Likert-type scale with 5 options consisting of never, occasionally, sometimes, often, and always. The researchers gave the final version of the scale at the end of three stages. In the first stage; 24 items were created and data were collected with 300 students. In the second step; 3 items were removed and the 21- 
item version was applied to 400 students, and in the third stage, exploratory factor analysis was conducted to assess the validity and reliability of the scale. As a result of the Factor Analysis, 3 items were removed from the scale; It was determined that the remaining 18 items explained 48,557\% of the total variance and gathered in 4 factors. Cronbach's Alpha index was calculated for the reliability of the 18-items scale whose validity had been approved and it was found 0,812 for the whole scale. As a result of the analysis, a 3-dimensional, 16-item scale with proven validity and reliability has emerged with Cronbach Alpha values of $.85, .69, .53$, and .50 , respectively.

\section{Procedure}

The participants of the study were chosen from eight fourth-grade classes from primary schools located in Artvin. These 8 classes were randomly assigned the following conditions: the traditional non-game group (regular teaching) or the game group (regular teaching + playing Slice Fractions game). By the time this study was conducted, all lessons were delivered via online learning platforms due to the COVID-19 pandemic. Before the teachers started to fractions unit, the students completed the web-based pre-test questionnaire individually in synchronized online classes. After completing the pre-test questionnaire, all students in both groups started to take lessons about fractions. In the game group, the teachers asked their students to download Slice Fractions game to their smartphones or tablets. They provided detailed information about the game. The traditional group had no additional learning materials while the game group played the Slice Fractions game. For groups playing the game, students had four separate one-hour periods to complete as many levels as possible (1 hour per week for 4 weeks).

\section{Data Analysis}

To investigate the potential differences between the control (non-game) and the experimental (game) groups regarding the learning performance and self-efficacy in fractions collected in the pre-test questionnaire, Levene's test of homogeneity of variances was performed. After investigating the potential differences of the two groups before the intervention, the paired-samples t-test was used to investigate the effectiveness of both learning methods on students' knowledge and self-efficacy of fractions. Finally, the repeated measures of ANOVA test was used to illustrate the main and interaction effects on the variables. All of the analyses were performed using the SPSS 19.0 application with a significance level of 0.05 .

\section{RESULTS}

\section{Comparison of the two groups with regard to the knowledge tests}

The first purpose of this study was to explore the effectiveness of the game-based app in terms of improving the learning performance of the students in fractions. In each knowledge test questionnaire (pre-test and post-test), the students could score up to 15 points. The mean values and standard deviations of the pre-test scores were 8.93 and 3.43 for the non-game group, and 7.17 and 3.68 for the game group. The analysis of Levene's test showed that there was no statistically significant difference between the two groups with, $[\mathrm{F}(1,140)=0.925, \mathrm{p}=0.338]$. Therefore, this indicates that the two groups of students had equivalent prior knowledge before the intervention.

The results for the paired-samples $t$ test showed a statistically significant difference for both groups with $[\mathrm{t}=-2.61, \mathrm{p}=0.01]$ between the pre-test $(\mathrm{M}=8.93, \mathrm{SD}=3.43)$ and the post-test $(\mathrm{M}=9.76, \mathrm{SD}=3.46)$ for the non-game group and $[\mathrm{t}=-10.39, \mathrm{p}=0.00]$ between the pre-test $(\mathrm{M}=7.17, \mathrm{SD}=3.68)$ and the 
post-test $(\mathrm{M}=12.11, \mathrm{SD}=3.00)$ for the game group respectively. Consequently, it can be concluded that the students in both groups gained some new information during the two types of classes.

Finally, the results of the repeated measures of ANOVA indicate a significant main effect of time, $\mathrm{F}(1,142)=585.80, \mathrm{p}=0.001, \eta 2=0.580 ;$ a significant interaction effect of group learning by time, $\mathrm{F}(1,142)=298.29, \mathrm{p}=0.001, \eta 2=0.429$. Thus, it can be concluded that there was a difference in the students' learning performance before and after exposure to group learning as measured and indicated by the pre-test and post-test scores of the students' learning of the fraction concept. The results showed that there was an interaction between group learning and test time. Thus, these findings imply that gamebased intervention had a significant impact in improving students' learning performance.

\section{Comparison of the two groups with regard to the self-efficacy tests}

The second purpose of this study was to explore the effectiveness of the game-based app in terms of improving the students' self-efficacy in fraction skills. In each self-efficacy scale test (pre-test and posttest), the students could score up to 90 points. The mean values and standard deviations of the pre-test scores were 57.79 and 9.26 for the non-game group, and 56.47 and 10.53 for the game group. The analysis of Levene's test showed that there was no statistically significant difference between the two groups with, $[F(1,140)=1.608, p=0.112]$. Thus, this shows that the two groups of students had equivalent selfefficacy scores towards the fraction skills before the intervention.

The results for the paired-samples $t$ test showed that there is no statistically significant difference for non-game groups with $[\mathrm{t}=1.17, \mathrm{p}=0.245]$ between the pre-test $(\mathrm{M}=57.79, \mathrm{SD}=9.26)$ and the posttest $(\mathrm{M}=59.16, \mathrm{SD}=11.00)$ for the non-game group. However, the results showed a statistically significant difference for game groups with and $[\mathrm{t}=-3.08, \mathrm{p}=0.003]$ between the pre-test $(\mathrm{M}=56.06$, $\mathrm{SD}=10.37)$ and the post-test $(\mathrm{M}=63.87, \mathrm{SD}=9.49)$ respectively. Therefore, it can be concluded that the students' self-efficacy towards learning fractions increased in game groups.

Finally, the results of the repeated measures of ANOVA indicate a significant main effect of time, $\mathrm{F}(1,142)=1476.6, \mathrm{p}=0.001, \eta 2=0.232$; a significant interaction effect of group learning by time, $\mathrm{F}(1,142)=726.4, \mathrm{p}=0.001, \eta 2=0.180$. Thus, it can be concluded that there was a difference in the students' self-efficacy scores before and after exposure as measured and indicated by the pre-test and post-test scores of the students' self-efficacy of the fraction concept. Thus, these findings imply that game-based intervention had a significant impact in improving students' self-efficacy in fractions skills.

\section{DISCUSSION}

This research aimed to examine the effectiveness of a game-based app (Slice Fractions) to help students to develop their academic achievement and self-efficacy during distance education. According to the findings of the study, it was seen that the success scores of the experimental group students who received a game-based mobile application-supported education in addition to distance education lead to a higher increase in the subject of fractions than the control group students who only received distance education, and the students' level of comprehension of this subject increased. In addition, it was found that the mathematics course carried out with the digital video game-supported educational activities had a positive effect on the students' self-efficacy beliefs about fractions. As a result, it was determined that the experimental group students showed a significant difference in their self-efficacy beliefs and academic achievements about fractions, which is one of the important topics in mathematics. 
These results are similar in terms of the positive contribution to the learning outcomes of the students to previous studies that have examined the effectiveness of using a game-based app in mathematics education. For instance, As stated in the studies of Cyr et al. (2019), the mobile compatible digital video game, which provides active participation and allows multiple displays, offers students effective learning in an educational process. It is even stated that because of this process and its advantages, educational games are being used more as complementary teaching tools for mathematics education. In addition, in this study, it was revealed that the use of the game caused a significantly greater increase in learning compared to the traditional teaching without the use of games. As one of the reasons for this, educational games create cognitive conflicts in individuals and put users in a state of imbalance (Annetta, 2010). Learning results from the resolution of these conflicts. From Piaget's point of view, learners use these new experiences and relate them to previous knowledge so that they can absorb new knowledge (the concept of fractions). It has been stated that the Slice Fractions game, designed for educational purposes, helps students who have no previous knowledge about fractions to understand intuitively and move to a more abstract understanding through virtual manipulatives (Cyr et al., 2019). In addition, it is stated in the literature that the use of technological tools is an effective approach because it allows students to manipulate the visual representations of fractions in a virtual environment and thus helps students understand (Aslan, 2011; Moyer-Packenham \& Bolyard, 2016). Similarly, Simsek (2016) stated that, according to the results of his study, all students' knowledge and skills about fractions improved after interacting with the mobile application called Motion Math: Fraction, and even after a long break from using it, it maintained its permanence.

Research reveals that when used effectively, digital game-based learning environments increase students' performance, interest, motivation, and self-efficacy (Hung et al., 2014; Wouters et al., 2013; Yu, 2019). Unlike entertainment games, digital video games are designed for education rather than entertaining (Nazry et al., 2017). One of the reasons why mobile-based educational games are effective in education may be their effects on students' affective states. Game-based mobile applications that offer a recreational environment play an important role in the formation of affective states such as sadness, happiness, and anger (ibid). Effective educational video games try to create a positive motivation to encourage users to keep playing, which helps increase interest in the game and demonstrate better academic achievement. In line with these results, it has been determined that both learning environments have different effects on increasing the success of the students, and supporting distance education with a game-based mobile application in addition to the process is more effective in increasing the achievement and self-efficacy of the students.

\section{Limitations and Implications}

This study is a quasi-experimental study with a control group to explore the effect of a game-based mobile application on the mathematics achievement and self-efficacy beliefs of fractions of 4th-grade students who learn fractions in the process of distance education. The study, which presents a theoretical framework and empirical evaluations in line with the findings, has some limitations. The first of these limitations is that due to the fact that the study is quasi-experimental, it was carried out on a limited number of students and in a limited time. Although all statistical results in the study give positive results on the suitability of the group, this may limit the generalizability of the results of the study. The second limitation is to be handled within the framework of a certain subject and to choose suitable mobile applications in this direction. As a matter of fact, although this is the right approach, the suitability of the 
preferred mobile application in future studies and the management of the process may lead to different results.

It is considered that this study has important contributions to both theory and practice in the field of mathematics education in terms of revealing the effectiveness and benefits of technology use in mathematics education and a digital game-based mobile application supported mathematics education applications. In line with the purpose of the study, we can state that a digital game-based application contributes to students' associating mathematics with daily life, embodying abstract concepts and making sense of these concepts in the teaching of fractions, which is one of the complex and difficult subjects of mathematics. As a matter of fact, this situation is an indicator of the success achieved, as well as the positive development in students' self-efficacy perceptions. On the other hand, the main source of the experimental group being much more successful than the control group as a result of the study may be the mobile application or teaching method used. Although it is very difficult to give a clear answer to this situation, which is also seen as one of the limitations of the study, it is possible to say that all elements in the implementation process have the potential to affect success, according to the findings obtained from this research. In this direction, based on the results obtained from the research;

- Using mobile technologies that can be used anytime and anywhere, as well as digital video games that allow learning while having fun, in mathematics education,

- Supporting the processing of mathematical subjects by establishing a connection with real-life with appropriate methods and techniques,

- Supporting the use of technology and accompanying applications in the process that will contribute to the teaching of mathematics by students,

- Carrying out similar studies in other levels of education and other mathematics subjects, recommendations are made. 


\section{REFERENCES}

Aksu, Z. \& Konyalığlu, A.C. (2015). Sınıf öğretmen adaylarının kesirler konusundaki pedagojik alan bilgileri [PreService Primary School Teachers' Pedagogical Content Knowledge In Fractions]. Kastamonu Education Journal. 23(2), 723-738. https://dergipark.org.tr/tr/pub/kefdergi/issue/22599/241424

Alacaci, C. (2015). Öğrencilerin kesirler konusundaki kavram yanılgılar1 [Students'misconceptions about fractions]. In E. Bingölbali, \& M. F. Özmantar (Eds.), İlkëgretimde karşzlaşılan matematiksel zorluklar ve çözü̈m öneriler [Mathematical difficulties encountered in primary education and Suggestions]. Ankara: PegemA.

Annetta, L. A. (2010). The "I's" have it: A framework for serious educational game design. Review of General Psychology, 14(2), 105-112. https://doi.org/10.1037/a0018985

Bailey, D. H., Hoard, M. K., Nugent, L., \& Geary, D. C. (2012). Competence with fractions predicts gains in mathematics achievement. Journal of Experimental Child Psychology, 113(3), 447-455. https://doi.org/10.1016/j.jecp.2012.06.004.

Bandura, A. (1982). Self-efficacy mechanism in human agency. American Psychologist, 37(2), 122-147. https://doi.org/10.1037/0003-066X.37.2.122

Bandura, A. (1997). Self-efficacy: The exercise of control. New York: W.H. Freeman.

Berch, D. B., \& Mazzocco, M. M. (2007). Why is math so hard for some children? The nature and origins of mathematical learning difficulties and disabilities. Brookes Publishing Company.

Bonne, L., \& Johnston, M. (2016). Students' beliefs about themselves as mathematics learners. Thinking Skills and Creativity, 20, 17-28. https://doi.org/10.1016/j.tsc.2016.02.001

Brousseau, G., Brousseau, N., \& Warfield, V. (2004). Rationals and decimals as required in the school curriculum. Part 1: rationals as measurements. The Journal of Mathematical Behavior, 23(1), 1-20. https://doi.org/10.1016/i.jmathb.2003.12.001

Bruce, C. D., \& Ross, J. (2009). Conditions for effective use of interactive online learning objects: The case of a fractions computer-based learning sequence. Electronic Journal of Mathematics and Technology, 3(1). https://php.radford.edu/ ejmt/deliverAbstract.php?paperID=eJMT v3n1p2

Bulgar, S. (2003). Children's sense - making of division of fractions. The Journal of Mathematical Behavior, 20(3), 319334. https://doi.org/10.1016/S0732-3123(03)00024-5

Büyüköztürk, Ş., Çakmak, E., Akgün, Ö. E., Karadeniz, Ş., \& Demirel, F. (2008). Bilimsel Araștrma Yöntemleri [Scientific Research Methods]. Ankara: Pegem A Yayıncllik.

Cajori, F. (1999). A History of Mathematics. New York. The Macmillan Company.

Carr, J. (2012). Does math achievement h'APP'en when iPads and game-based learning are incorporated into fifthgrade mathematics instruction? Journal of Information Technology Education: Research, 11(1), 269-286. http://www.jite.org/documents/Vol11/JITEv11p269-286Carr1181.pdf

Charalambous C. Y., \& Pitta-Pantazi, D. P. (2005). Revisiting a theoretical model on fractions: Implications for teaching and research. In Chick, H.L. and Vincent, J. L. (Eds.), Proceedings of the 29th Conference of the International Group for the Psychology of Mathematics Education (Vol 2), pp. 233 - 240.

Cohen, L., \& Manion, L. (1994). Research Methods in Education (4th ed.). London: Routledge

Cramer, K., \& Whitney, S. (2010). Learning rational number concepts and skills in elementary school classrooms. In D. V. Lambdin \& F. K. Lester, Jr. (Eds.), Teaching and learning mathematics: Translating research for elementary school teachers (pp. 15-22). Reston, VA: NCTM.

Cramer, K., Wyberg, T., \& Leavitt, S. (2008). The role of representations in fraction addition and subtraction. Mathematics Teaching in The Middle School, 13(8), 490-496. https://doi.org/10.5951/MTMS.13.8.0490 
Cyr, S., Charland, P., Riopel, M., \& Bruyère, M.H. (2019). Integrating a game design model in a serious video game for learning fractions in mathematics. Joumal of Computers in Mathematics and Science Teaching, 38(1), 5-29. Waynesville, NC USA: Association for the Advancement of Computing in Education (AACE). https://www.learntechlib.org/primary/p/183506/

Cyr, S., Charland, P., Riopel, M., \& Bruyère, M.-H. (2019). Integrating a game design model in a serious video game for learning fractions in mathematics. Journal of Computers in Mathematics and Science Teaching, 38(1), 5 29. https://www.learntechlib.org/primary/p/183506/

DeWolf, M., Bassok, M., \& Holyoak, K. J. (2015). Conceptual structure and the procedural affordances of rational numbers: Relational reasoning with fractions and decimals. Journal of Experimental Psychology: General, 144(1), 127-150. https://doi.org/10.1037/xge0000034

Dickson, L., Brown, M., \& Gibson, O. (1993). Children learning mathematics: A teachers guide to recent research. London: Schools Council Publications.

Eroğlu, D., Camc1, F., \& Tanışlı, D. (2019). Hypothetical learning trajectory to the development of sixth grade students' knowledge about fractions and addition-subtraction in fractions. PAU Journal of Education, 45, 116143. https://doi.org/10.9779/PUJE.2018.225

Fabian, K., Topping, K. J., \& Barron, I. G. (2016). Mobile technology and mathematics: Effects on students' attitudes, engagement, and achievement. Journal of Computers in Education, 3(1), 77-104. https://doi.org/10.1007/s40692-015-0048-8

Gabriel, F. C., Coché, F., Szucs, D., Carette, V., Rey, B., \& Content, A. (2013). A componential view of children's difficulties in learning fractions. Frontiers in psychology, 4, 715. https://doi.org/10.3389/fpsyg.2013.00715

Haser, C.., \& Ubuz, B. (2003). Student's conception of fractions: a study of 5th grade students. Hacettepe University Journal of Faculty of Education, 24(24), 64-69. http://efdergi.hacettepe.edu.tr/yonetim/icerik/makaleler/909published.pdf

Hecht, S. A., \& Vagi, K. J. (2012). Patterns of strengths and weaknesses in children's knowledge about fractions. Journal of Experimental Child Psychology, 111(2), 212-222. https://doi.org/10.1016/i.jecp.2011.08.012

Hecht, S. A., Vagi, K. J., \& Torgesen, J. K. (2007). Fraction skills and proportional reasoning. In D. B. Berch \& M. M. M. Mazzocco (Eds.), Why is mathematics so hard for some children? The nature and origins of mathematics learning difficulties and disabilities (pp.121-132). Baltimore, MD: Paul H. Brookes.

Hung, C. M., Huang, I., \& Hwang G. J. (2014). Effects of digital game-based learning on students' selfefficacy, motivation, anxiety, and achievements in learning mathematics. Journal of Computers in Education, 1(2-3), 151 166. https://doi.org/10.1007/s40692-014-0008-8

İpek, A.S., Işı1k, C., \& Albayrak, M. (2005). Conceptual performance of prospective primary teachers on operations with fractions. Kažm Karabekir Eğitim Fakültesi Dergisi, 1, 537-547. https://dergipark.org.tr/tr/download/article-file/31446

Jones, J. C. (2012). Visualizing elementary and middle school mathematics methods. USA: John Wiley \& Sons.

Kauchak, D., P. ve Eggen, P., D. (1998). Learning and teaching. Third Edition. Boston: Allyn and Bacon.

Kerslake, D. (1986). Fractions: Children's strategies and errors. A report of the strategies and errors in secondary mathematics project. Windsor, Berkshire, England: NFER - NELS.

Lamon, S. J. (2012). Teaching fractions and ratios for understanding: Essential knowledge and instructional strategies for teachers. New York: Routledge/Taylor \& Francis Group.

Lee, Y. L. (2010). Enhancement of Fractions from Playing a Game. New Zealand mathematics magazine, 47(1), 30-40. www.merga.net.au/documents/Lee RP09.pdf.

Leung I. K. C., \& Carbone R. E. (2013). Pre-service teachers' knowledge about fraction division reflected through problem posing. The Mathematics Educator, 14(1-2), 80-92. 


\section{https://repository.eduhk.hk/en/publications/pre-service-teachers-knowledge-about-fraction-divisions-} reflected-5

Long, C. T., DeTemple, D. W., \& Millman, R. S. (2015). Mathematical reasoning for elementary teachers (7th. Edition). UK: Pearson Education Limited.

Lortie - Forgues, H., Tian, J., \& Siegler, R. S. (2015). Why is learning fraction and decimal arithmetic so difficult?. Developmental Review, 38, 201-221. https://doi.org/10.1016/i.dr.2015.07.008

Masek, M., Boston, J., Lam, C., \& Corcoran, S. (2017). Improving mastery of fractions by blending video games into the math classroom. Journal of Computer Assisted Learning, 33(5), 486499. https://doi.org/10.1111/jcal.12194.

Milli Eğitim Bakanlığı [MEB]. (2018). Matematik Dersi Öğretim Programı (İlkokul ve ortaokul 1, 2, 3, 4, 5, 6, 7 ve 8. siniflar) [Turkish 1-8 grade mathematics curriculum]. http://mufredat.meb.gov.tr/ProgramDetay.aspx?PID=329.

Moyer-Packenham, P. S., \& Bolyard, J. J. (2016). Revisiting the definition of a virtual manipulative. In P. S. MoyerPackenham (Ed.), International perspectives on teaching and learning mathematics with virtual manipulatives (pp. 3-23). Springer.

Musti-Rao, S., \& Plati, E. (2015). Comparing two classwide interventions: Implications of using technology for increasing multiplication fact fluency. Journal of Behavioral Education, 24 (4), 418-437. https://doi.org/10.1007/s10864-015-9228-x

Naiser, E. A., Wright, W. E., \& Capraro, R. M. (2003). Teaching fractions: Strategies used for teaching fractions to middle grade students. Journal of Research in Childhood Education, 18(3), 193-198. https://doi.org/10.1080/02568540409595034

Nazry, N., Nazrina, M., \& Romano, D. M. (2017). Mood and learning in navigation based serious games. Computers in Human Behavior, 73, 596-604. https://doi.org/10.1016/j.chb.2017.03.040

$\mathrm{Ni}$, Y., \& Zhou, Y. D. (2005). Teaching and learning fraction and rational numbers: the origins and implications of whole number bias. Educional Psychologist, 40(1), 27-52. https://doi.org/10.1207/s15326985ep4001 3

Olkun, S., \& Toluk Uçar, Z. (2014). Illkëgrretimde etkinlik temelli matematik ögretimi [Activity-based mathematics teaching in primary education] (6. Ed.). Ankara: Eğiten Kitap Yayınları.

Pesen, C. (2007). Students' misconceptions about fractions. Education and Science, 32(143), 79-88. http://egitimvebilim.ted.org.tr/index.php/EB/article/view/833/186

Peters, M. L. (2013). Examining the relationships among classroom climate, self-efficacy, and achievement in undergraduate mathematics: A multi-level analysis. International Journal of Science and Mathematics Education, 11(2), 459-480. https://doi.org/10.1007/s10763-012-9347-y

Reychav, I., \& Wu, D. (2014). Exploring mobile tablet training for road safety: A uses and gratifications perspective. Computers \& Education, 71, 43-55. https://www.learntechlib.org/p/200573/

Riconscente, M. (2011). Mobile learning game improves 5th graders' fractions knowledge and attitudes. Los Angeles, CA: GameDesk Institute.

Riconscente, M. M. (2013). Results from a controlled study of the iPad fractions game Motion Math. Games and Culture, 8(4), 186-214. https://doi.org/10.1177/1555412013496894

Siegler, R. P., Carpenter T., Fennell F., Geary D., Lewis J., Okamoto Y., Thompson L., \& Wray J. (2010). Developing effective fractions instruction for kindergarten through 8th grade (NCEE 2010-4039). Washington, DC: U.S. Department of Education, Institute of Education Sciences, National Center for Education Evaluation and Regional Assistance.

Siegler, R. S., Fazio, L. K., Bailey, D. H., \& Zhou, X. (2013). Fractions: the new frontier for theories of numerical development. Trends in cognitive sciences, 17(1), 13-19. https://doi.org/10.1016/i.tics.2012.11.004 
Siegler, R. S., Thompson, C. A., \& Schneider, M. (2011). An integrated theory of whole number and fractions development. Cognitive Psychology, 62(4), 273 - 296. https://doi.org/10.1016/i.cogpsych.2011.03.001

Simsek, O. (2016). Use of a game-based app as a learning tool for students with mathematics learning disabilities to increase fraction knowledge/skill [Unpublished Doctoral dissertation]. University of South Florida.

Sowder, J. T. (1995). Instructing for rational number sense. In J. T. Sowder \& B. P. Schappelle (Eds.), Providing a foundation for teaching mathematics in the middle grades (pp. 15-30). Albany, NY: State University of New York Press.

Soylu Y., \& Soylu, C. (2005). Learning difficulties of 5th class in primary education at fractions: Ordering, adding, subtraction, multiplication in fraction and problems related to fraction. Erzincan University Journal of Education Faculty, 7(2), 101-117. https://dergipark.org.tr/tr/pub/erziefd/issue/6005/80075

Suh, J. M., \& Moyer-Packenham, P. S. (2008). Suh, J. M., \& Moyer-Packenham, P. S. (2008, July). Scaffolding special needs students' learning of fraction equivalence using virtual manipulatives. In O. Figueras, J. L. Cortina, S. Alatorre, T. Rojano, \& A. Sepulveda (Eds.), Proceedings of the 32nd annual conference of the International Group for the Psychology of Mathematics Education (PME) (Vol. 4, pp. 297-304), Morelia, Mexico

Uz, I. (2018). Investigation of 5th grade of middle school students' self-efficacy toward fractions [Unpublished Master Thesis]. Dokuz Eylül University.

Van de Walle, J. A., Karp, K. S., \& Bay-Williams, J. M. (2013). Elementary and middle school mathematics: Teaching developmentally (8th ed.). Upper Saddle River, NJ: Pearson.

Van Hoof, J., Degrande, T., Ceulemans, E., Verschaffel, L., \& Van Dooren, W. (2018). Towards a mathematically more correct understanding of rational numbers: A longitudinal study with upper elementary school learners. Learning and Individual Differences, 61, 99-108. https://doi.org/10.1016/j.lindif.2017.11.010.

Watts, T. W., Duncan, G. J., Siegler, R. S., \& Davis-Kean, P. E. (2014). What's past is prologue relations between early mathematics knowledge and high school achievement. Educational Researcher, 43(7), 352-360. https://doi.org/10.3102/0013189X14553660

Wouters, P., Van Nimwegen, C., Van Oostendorp, H., \& Van Der Spek, E. D. (2013). A meta-analysis of the cognitive and motivational effects of serious games. Journal of Educational Psychology, 105(2), 249-265. https://doi.org/10.1037/a0031311

Yu, Z. (2019). A meta-analysis of use of serious games in education over decade. International Journal of Computer Games Technology, 1, 1-8. https://doi.org/10.1155/2019/4797032

Zhang, M., Trussell, R. P., Gallegos, B., \& Asam, R. R. (2015). Using math apps for improving student learning: An exploratory study in an inclusive fourth grade classroom. Tecbtrends: Linking Research And Practice To Improve Learning, 59(2), 32-39. https://doi.org/10.1007/s11528-015-0837-y 


\section{About Authors}

Metin Beşaltı received his bachelor's degree in Anadolu University, Computer Education and Instructional Technolgies Department in 2011. He completed his master's degrees in Instuctional Technolgy program at University of Texas at San Antonio in 2014 and his PhD degree in the sam program at the University of South Florida in 2019. He recently works as an Assistant Professor at the Artvin Coruh University, Faculty of Education, Department of Educational Sciences.

Ümit Kul obtained his bachelor's degree from Adnan Menderes University, Department of Mathematics in 2005, and also obtained his postgraduate diploma from the same university in 2007. He received his $\mathrm{PhD}$ degree in mathematics education at the University of Leicester in United Kingdom. Dr. Kul works as a Associate Professor at the Artvin Coruh University, Faculty of Education, Department of Mathematics and Science Education. His research interests include examining teacher's beliefs, self efficacy and pedagogical content knowledge, examination of curriculum and textbooks, and the use of technology in mathematics education.

\section{Author Contributions}

This study was conducted by all the authors working together and cooperatively. All of the authors substantially contributed to this work in each step of the study.

\section{Conflict of Interest}

It has been reported by the authors that there is no conflict of interest.

\section{Funding}

No funding support was received.

\section{Note}

We thank Francois Boucher-Genesse and all the members of the Ululab team to give us free accesses to use the Slice Fraction game in our study.

\section{Ethical Statement}

All procedures performed in studies involving human participants were in accordance with the ethical standards and with the Helsinki Declaration and its later amendments or comparable ethical standards. Informed consent was obtained from all individual participants included in the study. In line with this, the study was permitted by Artvin Coruh University Scientific Research and Ethical Review Board.

Ethics Committee Name: Artvin Coruh University, Scientific Research and Ethical Review Board Approval Date: 27/01/2021.

Approval Document Number: 18457941-050.01.04-2352 